\title{
Shift from Wicked Stepmother to Stepmother in Eastern and Western Fairy Tales
}

\author{
Geon Ho Bahn ${ }^{\bowtie}$ and Minha Hong ${ }^{2}$ \\ 'Deparment of Psychiatry, Kyung Hee University School of Medicine, Seoul, Republic of Korea \\ 2Department of Psychiatry, Hanyang University College of Medicine, Myongji Hospital, Goyang, Republic of Korea
}

Objective The image of the wicked stepmother has created a prejudice against stepmothers, which makes it difficult for them to adjust to their stepfamilies. This study compared fairy tales from different cultures to reestablish the nature of stepmothers.

Methods Grimms' Fairy Tales (GFT) was used to represent Western culture, with stepmother characters appearing in 15 out of 210 tales. "The Collection of Korean Traditional Fairy Tales" (KFT) was used to represent Eastern culture, with stepmother characters featured in 14 out of 15,107 tales. We examined the relationships between stepmothers and stepchildren in GFT and KFT.

Results Daughters were abused more often than sons in both genres. In GFT, jealousy spurred the abuse in 12 of 15 cases, while in KFT greed was predominant in 12 of 14 cases.

Conclusion The fairy tale portrayals of wicked stepmothers may be associated with the stigma children place on their stepmothers, which needs to be overcome.

Psychiatry Investig 2019;16(11):836-842

Key Words Stepparent, Culture, Folklore, Divorce, Marriage.

\section{INTRODUCTION}

Stepparents have found it more difficult to parent their stepchildren than to parent their biological children. ${ }^{1}$ Gender stratification perspectives suggest that stepmothers are more likely than stepfathers to experience role conflicts in acting as both a stepparent and a biological parent because they assume more childrearing responsibilities. ${ }^{2}$ In addition, in both Eastern and Western cultures, children are exposed to representations of wicked mothers. ${ }^{3}$ Therefore, the problems stepmothers' face can be attributed to difficulties in adjusting to family life and not the stepmothers' mental problems.

The prefix "step" continues to carry negative connotations, which amplifies conflicts between stepmothers and children. ${ }^{4}$ Even ancient Greeks and Romans assumed malevolence on the part of stepmothers. ${ }^{5}$ The most influential models of prej-

Received: May 26, 2019 Revised: July 18, 2019

Accepted: September 2, 2019

$\bowtie$ Correspondence: Geon Ho Bahn, MD, PhD

Department of Psychiatry, Kyung Hee University School of Medicine, 26 Kyungheedae-ro, Dongdaemun-gu, Seoul 02447, Republic of Korea

Tel: +82-2-958-8556, Fax: +82-2-957-1997, E-mail: mompeian@khu.ac.kr

(c) This is an Open Access article distributed under the terms of the Creative Commons Attribution Non-Commercial License (https://creativecommons.org/licenses/by$\mathrm{nc} / 4.0$ ) which permits unrestricted non-commercial use, distribution, and reproduction in any medium, provided the original work is properly cited. udice against stepmothers might come from two Disney animated films, "Snow White and the Seven Dwarfs" and "Cinderella". Both of these films are based on Grimms' Fairy Tales, in which archetypal stepmothers confront and persecute their stepdaughters. "Kongjwi and Patjwi" in Korea and "Komehuku and Awahuku" in Japan ${ }^{8}$ have similar plots to the German "Cinderella." When classifying Korea's ancient novels and fairy tales, "stepmother stories" are in a separate category from other themes. ${ }^{9}$ Appearance of stepmothers in East and West folklore reflects a historic concern over the stepmother's presence.

High divorce and remarriage rates mean that many modern families have stepmothers. Despite evidence that stepmothers experience considerable stress associated with their roles, few studies have examined the impact of stepmother stereotypes on children or focused on how to cope with the wicked stepmother stereotype and stigma. ${ }^{3}$ How should we reinterpret the past to overcome the current prejudice against stepmothers and related family members? To answer this question, folktales can be used to study cultures. ${ }^{10}$ Because folktales have been animated or turned into movies, they are well known to the public, which will make it easier for people to grasp and share this study's results. If we understand the root of the conflicts and their cultural meanings, we can identify 
better ways to resolve issues created by prejudice against stepmothers. Therefore, in this study, we analyzed and compared folktales from Eastern and Western cultures, including stepmother stories from Korean literature and Grimms' Fairy Tales.

\section{METHODS}

\section{Subjects: Grimm's Fairy Tales}

The authors selected "Kinder Und Hausmärhen," written in 1,865 by Jacob Grimm and Wilhelm Grimm, to represent Western culture, as it ranks among the best-selling books in the West, along with the Holy Bible and the works of Shakespeare. ${ }^{11}$ The original version of Grimms' Fairy Tales (GFT) was written in German. The authors read the English version, "The Complete Fairy Tales of the Brothers Grimm"12 as a main reference. Among 210 tales, we found stepmothers appeared in 15 stories: "The Brother and Sister," "Rapunzel," "The Three Little Men in the Wood," "Cinderella," "Mother Hulda," "The Six Swans," "Snow White," "Roland," "One-eye, Two-eyes, and Three-eyes," "The White Bride and Black One," "The Lambkin and the Little Fish," "The True Bride," "Hansel and Gretel," "The Riddle," and "The Juniper Tree."

\section{Subjects: Korean Fairy Tales}

The Academy of Korean Studies published "The Comprehensive Collection of Korean Oral Literature" over eight years from 1980 to 1989, which included 85 volumes, three of which were supplementary volumes. ${ }^{9}$ This collection includes 15,107 folktales, 6,187 folk songs, 376 traditional chants, and 21 miscellaneous writings. The 15,107 folktales represent Korean Fairy Tales (KFT). The content of these folktales is similar, differentiated by changes according to the province and storytellers, or according to the main character's identity or gender. Scholars at the Academy of Korean Studies classified many of these folktales into eight categories. ${ }^{9}$ Within those categories, type 4-4-1, "sins that ruin family relationships," includes 104 stories about bad stepmothers, while type 4-1-1, "protecting the right relationship between families even in difficult circumstances," has four tales about good stepmothers. ${ }^{13}$ Since GFT has no stories about good stepmothers, for this study's analysis, the authors excluded the good stepmother stories from KFT.

As these 104 folktales were expressed differently depending on the region or storytellers, the authors analyzed 104 folktales with bad stepmother characters and reclassified them into 14 KFT titles. The English titles and a brief synopsis are as follows, with respective credits to the "Encyclopedia of Korean Folk Literature" and related papers ${ }^{14,15}$ as noted.

1) Kongjwi and Patjwi. Kongjwi dies after being mistreated by her stepmother and her stepsister Patjwi. However, with help from supernatural beings, she overcomes her ordeals and returns to life. ${ }^{9}$

2) Son reborn as golden calf (or Ox that became the councilor's son-in-law). This is the story of a stepmother who tries to eat the liver of the first wife's son. ${ }^{9}$

3) Woomocnangsang (Stepmother who pulled out a stepson's eye). A stepson whose stepmother tricked him into pulling out his own eyes for his sick father is then reunited with his father and recovers his vision. ${ }^{9}$

4) Yeoni and willow bachelor. This is the story of a daughter, Yeoni, whose stepmother sent her out to pick herbs in the middle of a cold winter, but overcomes this ordeal with help from a bachelor possessing supernatural powers. ${ }^{9}$

5) Poisoning the son-in-law during hap-guel-lye* (*hapgeul-lye refers to a liquor sharing ceremony between the bride and the groom during a wedding). ${ }^{9}$

6) Poisonous apéritifs, medicinal digestifs. A stepmother served her stepson aperitifs at every meal so that he would become addicted and die and she could take over the property. Three years later, an elderly relative noticed that the son almost died. He helped the son change the aperitifs to medicinal digestifs, and the stepmother's conspiracy failed. ${ }^{15}$

7) A stepson in a well. A stepmother put her stepson in the well to kill him so that she could pass the property on to her own son, but the stepson dug a tunnel and escaped. ${ }^{15}$

8) Searching for husband's head. A stepmother killed her stepson on the night of his wedding and accused the bride, but the bride uncovered the plot and saved her own reputation. ${ }^{9}$

9) Hwanghwairyeop. A stepmother put a rat's shell in her unmarried stepdaughter's bed and announced that the stepdaughter aborted a fetus. The daughter was kicked out of the house. Later, the stepdaughter helped her boyfriend become a senior civil servant. They got married, and she returned home and punished her stepmother. ${ }^{14}$

10) Planting for the spring. A stepmother ordered her stepchildren to work in the farm. When the children became tired and slept for a while, she told her husband that the children did not obey her request. The angry father accidentally killed his children. ${ }^{15}$

11) Wise sang-gaeka*. A stepmother started a rumor that her stepdaughter had fallen in love with another man before marriage, to interfere with the wedding. A wise sang-gaek realized the stepmother's plans, controlled the situation, and successfully performed the wedding. ( ${ }^{*}$ sang-gaek means an elderly family member who accompanies the bride or groom). ${ }^{15}$

12) Jeopdongsae (lesser cuckoo). This is the story of a maiden harassed by her stepmother, who died and became a lesser cuckoo. ${ }^{9}$

13) Bride with no hands. This is the story of how a maiden, 
whose hands were cut off and whose stepmother plotted to have her thrown out of her home, got married, became a mother, and formed her own happy family. When she arrived at a well where she leaned in to fetch a drink of water, and her baby fell into the well, upon which she stretched out her arms to catch the baby, and her hands grew back in an instant. ${ }^{9}$

14) Janghwa and Hongnyeon. The haunted spirits of Janghwa and Hongnyeon, sisters killed by a stepbrother, appear as themselves in front of the magistrate to ask that the injustice against them be resolved. ${ }^{9}$

\section{Procedures}

The authors reviewed 15 stories from GFT and 14 stories from KFT. From these tales, the team found common motifs to interpret and compare them: the ex-wife's children (victims); cause of conflicts; the stepmother's punishment; the stepmother's children's attitude toward the victims (ex-wife's children); and the biological father's attitude toward family conflicts.

First, the authors identified the number of children from the ex-wives and their genders, then identified the victims (the children subject to abuse).

For the conflict cause, the authors read each folktale and selected keywords. After a full discussion, they decided on the keyword for each folktale, and then divided the stories into two categories representing reasons for abuse: greed and jealousy. Stories that included the following keywords fell under the "greed" category: poverty, wealth, labor, property, money, and wedding gift. These stories tended to feature a stepmother who abused an ex-wife's child to pass the property on to herself or her own child. Stories that included the following keywords were categorized as "jealousy": competition, appearance, beauty, ability, seclusion, and slandering. These stories featured a stepmother who mistreated an ex-wife's child who was better looking or more talented than herself or her own children.

The stepmother's punishment motif had three possible outcomes: she was punished, she was forgiven, or it was not mentioned.

For the stepmothers' children's attitude toward the victims' theme, we noted the number of children the stepmother had and their genders, and assessed whether they were friendly or hostile toward the ex-wife's children.

The biological father's attitude toward family conflicts is classified as follows: defers to the stepmother and joins in abusing his own daughter; directly punishes the stepmother in anger; is passive and has a small role in the plot; and is not mentioned at all.

If a widower with his own child marries a woman with her own child from her previous marriage, the man becomes a stepfather to the widow's child. In this study, the analysis of the relationship between the stepfather and the stepmother's child from her previous marriage was omitted because it is not relevant to this research topic.

\section{Ethics statement}

This study's protocol was approved by the Institutional Review Board of the Kyung Hee University Hospital (KMC IRB 1604-06).

\section{RESULTS}

In both GFT and KFT, the victims were more often daughters than sons. In GFT, daughters were victims in 10 of 15 tales, sons in two, and brothers and sisters in three (Table 1). In KFT, daughters were victims in eight of 14 tales, sons in five, and a brother and sister in one (Table 1).

The reasons for the abuse differed between GFT and KFT. In GFT, the stepmother abused the ex-wife's children out of jealousy in 12 of the 15 tales (Table 1). In seven stories, the stepmother abused the ex-wife's daughter because she was more beautiful and kind than her own daughter (Table 2), as is the case in "Snow White." "The six swans" is the only story

Table 1. Comparison between German Grimm's Fairy Tales and traditional Korean Fairy Tales

\begin{tabular}{|c|c|c|}
\hline & $\begin{array}{c}\text { Grimms' } \\
\text { Fairy Tales }\end{array}$ & $\begin{array}{c}\text { Korean } \\
\text { Fairy Tales }\end{array}$ \\
\hline \multicolumn{3}{|l|}{ Victims } \\
\hline Daughter & 10 & 8 \\
\hline Son & 2 & 5 \\
\hline Both & 3 & 1 \\
\hline \multicolumn{3}{|l|}{ Causes } \\
\hline Jealousy & 12 & 2 \\
\hline Greed & 3 & 12 \\
\hline \multicolumn{3}{|c|}{ Stepmother's punishment } \\
\hline Punishment & 10 & 9 \\
\hline Forgiveness & 1 & 1 \\
\hline None & 4 & 4 \\
\hline \multicolumn{3}{|c|}{ Stepmother's children's attitude toward the victims } \\
\hline Hostile & 7 & 2 \\
\hline Friendly & 1 & 0 \\
\hline None & 7 & 12 \\
\hline \multicolumn{3}{|c|}{ Biological father's attitude toward family conflicts } \\
\hline Agreement* & 2 & 7 \\
\hline Punishment ${ }^{\dagger}$ & 0 & 2 \\
\hline Passive & 3 & 1 \\
\hline None & 10 & 5 \\
\hline
\end{tabular}

*deferred to the stepmother and joined in abusing his own daughter, ${ }^{\dagger}$ directly punished the stepmother in anger 
in which stepmother's jealousy is directed at the sons, not at a daughter. The stepmother is jealous of the ex-wife's sons who monopolize her husband's love; so she turns them into swans. The reason why the daughter was not subjected to abuse in this tale is because the stepmother did not recognize she existed. In KFT, stepmothers abused the ex-wife's children to assume property or wealth in 12 of the 14 tales (Table 1). In two folktales, "Kongjwi and Patjwi" and "Bride with no hands", the stepmothers were jealous of the ex-wives' daughters who were excellent at their work (Table 3).

In ten stories from GFT and nine stories from KFT, the stepmother was punished in the end (Table 1). There was one tale each in both GFT and KFT in which the stepmother is forgiven. There were four tales in each in which either it was unclear whether the stepmother was punished or her outcome was not discussed.

Table 2. Content analysis of Grimms' Fairy Tales

\begin{tabular}{|c|c|c|c|c|c|c|c|}
\hline \multirow{2}{*}{$\begin{array}{l}\text { Cause } \\
\text { of abuse }\end{array}$} & \multirow{2}{*}{ Title } & \multicolumn{2}{|c|}{ Biological mother } & \multicolumn{3}{|c|}{ Stepmother } & \multirow{2}{*}{ Biological father ${ }^{\dagger}$} \\
\hline & & Children & Victims & Punishment & Children & Attitude* & \\
\hline \multirow{12}{*}{ Jealousy } & The brother and sister & 1 son, 1 daughter & 1 son, 1 daughter & Punishment & 1 daughter & Hostile & None \\
\hline & Rapunzel & 1 daughter & 1 daughter & None & None & - & Agreement \\
\hline & The three little men in the wood & 1 daughter & 1 daughter & Punishment & 1 daughter & Hostile & None \\
\hline & Cinderella & 1 daughter & 1 daughter & Punishment & 2 daughters & Hostile & Passive \\
\hline & Mother hulda & 1 daughter & 1 daughter & Punishment & 1 daughter & Hostile & None \\
\hline & The six swans & 6 sons, 1 daughter & 6 sons & None & None & - & Passive \\
\hline & Little snow white & 1 daughter & 1 daughter & Punishment & None & - & None \\
\hline & Roland & 1 daughter & 1 daughter & Punishment & 1 daughter & Hostile & None \\
\hline & One-eye, two-eyes, and three-eyes & 1 daughter & 1 daughter & Forgiveness & 2 daughters & Hostile & None \\
\hline & The white bride and the black one & 1 son, 1 daughter & 1 daughter & Punishment & 1 daughter & Hostile & None \\
\hline & The lambkin and the little fish & 1 son, 1 daughter & 1 son, 1 daughter & None & None & - & None \\
\hline & The true bride & 1 daughter & 1 daughter & Punishment & None & - & None \\
\hline \multirow[t]{3}{*}{ Greed } & Hansel and gretel & 1 son, 1 daughter & 1 son, 1 daughter & Punishment & None & - & Agreement \\
\hline & The riddle & 1 daughter & 1 daughter & None & None & - & None \\
\hline & The juniper tree & 1 son & 1 son & Punishment & 1 daughter & Friendly & Passive \\
\hline
\end{tabular}

*the stepmother's children's attitude toward the ex-wife's children, the biological father's attitude toward family conflicts

Table 3. Content analysis of Korean Fairy Tales

\begin{tabular}{|c|c|c|c|c|c|c|c|}
\hline \multirow{2}{*}{$\begin{array}{l}\text { Cause } \\
\text { of abuse }\end{array}$} & \multirow{2}{*}{ Title } & \multicolumn{2}{|c|}{ Biological mother } & \multicolumn{3}{|c|}{ Stepmother } & \multirow{2}{*}{ Biological father ${ }^{\dagger}$} \\
\hline & & Children & Victim & Punishment & Children & Attitude* & \\
\hline \multicolumn{2}{|c|}{ Jealousy Kongjwi and Patjwi } & 1 daughter & 1 daughter & Punishment & 1 daughter & Hostile & None \\
\hline & Bride with no hands & 1 daughter & 1 daughter & Punishment & None & - & Agreement \\
\hline \multirow[t]{12}{*}{ Greed } & Searching for husband's head & 1 son & 1 son & Punishment & 1 son & - & Punishment \\
\hline & Jepdongsae & 9 sons, 1 daughter & 1 daughter & Punishment & None & - & Agreement \\
\hline & Son reborn as golden calf & 1 son & 1 son & Punishment & None & - & Agreement \\
\hline & Hwanghwairyeop & 1 daughter & 1 daughter & Punishment & None & - & Agreement \\
\hline & Woomocnangsang & 1 son & 1 son & Punishment & 1 son & - & Agreement \\
\hline & Yeoni and willow bachelor & 1 daughter & 1 daughter & None & None & - & None \\
\hline & Jangwha and Hongnyeon & 2 daughters & 2 daughters & Punishment & 1 son & Hostile & Agreement \\
\hline & Poisoning the son-in-law & 1 daughter & 1 daughter & None & None & - & None \\
\hline & Poisonous Aperitifs & 1 son & 1 son & None & 1 son & - & None \\
\hline & Planting for the spring & 1 son, 1 daughter & 1 son, 1 daughter & None & None & - & Agreement \\
\hline & A stepson in a well & 1 son & 1 son & Forgiveness & 1 son & - & Agreement \\
\hline & Wise sang-gaek & 1 daughter & 1 daughter & Punishment & None & - & None \\
\hline
\end{tabular}

*the stepmother's children's attitude toward the ex-wife's children, the biological father's attitude toward family conflicts 
The stepmother's children featured in eight stories from GFT and in six stories from KFT (Table 1). In GFT, the stepmother's children were hostile toward the ex-wives' children in seven stories and friendly in one (Table 2). In two stories from KFT, the stepmother's children were hostile to the exwives' children, and their relationship was uncertain in the other four stories (Table 3).

With regard to the biological father's attitude toward family conflicts, there were ten stories from GFT in which there were no mention of fathers at all, two in which the fathers deferred to the stepmothers and joined in abusing their own daughters, and three in which the fathers were passive (Table 1). In KFT, eight fathers sympathized with stepmothers, one punished the stepmother, and five fathers' roles were not discussed (Table 1).

\section{DISCUSSION}

Stepmothers were well known as wicked in both GFT and KFT. Stepmothers made careful plans to take the inherited property of the ex-wife's child, or to abuse and even murder a child who was better looking or more talented. However, in this study, the authors found the reasons behind the stepmothers' evil doings were quite different between the East and West.

\section{Ex-wife's children, victims}

Conflicts in folktales between stepmothers and ex-wives' children occur more frequently between stepmothers and daughters than between stepmothers and sons. ${ }^{16}$ In this study, more daughters than sons were abused both cultures. The frequency of daughters being abused was higher in GFT compared to KFT. Interestingly, in KFT, the stepmothers hurt daughters-in-law or sons-in-law in addition to ex-wives' children. Consequently, stepdaughters assume the roles of innocent martyrs and patient sufferers. ${ }^{11}$ There are three hypotheses about the conflicts between stepmothers and the ex-wives daughters. One hypothesis is a psychodynamic one in which that the stepdaughter is viewed as a mediator of the ex-wife, so the confrontation between a stepmother and stepdaughter is actually between the stepmother and the ex-wife. ${ }^{9}$ Another hypothesis is the stepmother is envious because the stepchild monopolizes her husband's love. ${ }^{17}$ The third hypothesis based on the cultural and historical background suggests that, because of the high mortality rate among childbearing women at the time the folktales were written, widowed men would often marry much younger women. As such, there would be little age difference between the biological daughter and the stepmother, which created a dynamic open to much of the jealousy and competition seen between the fe- male characters within fairy tales. ${ }^{16}$

\section{Cause of conflicts}

The reasons for the abuse were different in GFT and KFT. In GFT, witches appear in the form of old women and stepmothers, who are described as having evil personalities. Historically, a witch was a supernatural and neutral being who cared for the human beings' residences. However, in the 15th century, the witch developed a negative image through Christian persecution and witch hunts. ${ }^{18}$ In the early 19 th century, when the Grimm brothers were collecting folktales, the positive image of stepmothers representing a matrilineal society was eliminated with the establishment of the patriarchal system. The negative stepmother was identified as a witch and played the villain's role, which seems to have been reflected in folklore. ${ }^{11}$ Even though a stepmother is a witch or has magic powers, she cannot overcome her stepchildren's appearances or abilities. Therefore, the witch stepmother becomes jealous of her stepchildren. It seems that rather than the stepmother originally being born a witch, the story-makers or story-tellers have overlapped the image of a witch, which was then considered a manifestation of evil, upon the stepmother. ${ }^{19}$

Some jealous and wicked stepmothers originated from the author's edit. ${ }^{11}$ Wilhelm Grimm had become aware that the collection had evolved into bedtime stories for children rather than as a source of entertainment for adults. As he recognized that most children can tolerate the idea of wicked stepmothers easier than that of cruel mothers, heartless biological mothers from "Hansel and Gretel," "Snow White," and "Mother Hulda" were transformed into stepmothers in successive editions of the tales.

Compared to GFT, in which jealousy prevails, the predominant reason for abuse in KFT is a desire for property, as related to Korea's historical background. Many Korean folktales with stepmothers as protagonists are classified separately from other folktales with different themes. These tales mostly appeared in the mid-Joseon period, or after the 17th century, ${ }^{20}$ which connected to changes in the social system at that time. During the Goryeo Dynasty (918-1392) and the early phase of the Joseon dynasty (1392-1910), stepfathers were more common than stepmothers. If a husband died, a widow lived with her children and her own family. If she remarried, her second husband would live at her house and become a stepfather. Let us compare the opposite. If a wife died, a widower lived separately, but his children lived with maternal families. If he remarried, he would live with his new wife's children and he would be a stepfather. With the settlement of neo-Confucianism and a stronger patriarchal system following the 16th and 17th centuries, the practice of a husband living in his wife's house was destroyed. After the 
17th century, a wife would live in her husband's home as a mother to his children. This created conflicts, especially between stepmothers and stepchildren, because the ex-wife's children were in a position to regard a stepmother as a mother. The conflict between the ex-wife's children and stepmothers, thus, led to a property dispute. ${ }^{20}$ From these historical and cultural changes in the ancient Korean society, we learned when Korean stepmother stories became popular and why have a shorter history compared with the western stories which started during ancient Greek and Roman times. ${ }^{21}$

\section{Punishment of a stepmother}

Most stepmothers who appear as bad in the folktales are punished at the end. Given that folktales aimed at children are intended for disciplinary purposes, such as gwonseonjingak (punishing evil and rewarding virtue), it's seems natural that stepmothers who commit evil deeds would be punished. ${ }^{9}$ On the other hand, a brutal punishment of a stepmother can be a reflection of society. ${ }^{18}$ Between the 14 th and 17 th centuries in Europe, the spiritual, religious, and political conditions rapidly changed, leading to cognitive instability. This change was viewed as the arrival of the devil's domination, which led to witch hunts. Therefore, this would have affected the punishments delivered in Grimms' Fairy Tales.

\section{Stepmother's children's attitude toward the victims (ex-wife's children)}

Most studies or books on stepfamilies refer only to stepparent-child relationships, and rarely note interactions between the ex-wife's children and stepmother's children. In the fairy tales included in this study, the relationship between the biological children and stepmothers' children in both the East and the West was described as unfriendly. Models of family relations and adolescent adjustment in stepfamilies, compared to non-divorced families, indicate more problems not only with the children's adjustment but also in parentchild and sibling relationships. ${ }^{22}$ The association seems to be parent-driven rather than child-driven. One of the fantasies and misconceptions that remarried parents hold on to is that they will successfully love each other, and their own children from previous marriages will love each other too. ${ }^{23}$ If stepmothers abuse stepchildren, the step siblings' relationships would be negative. Thus, if needed, therapeutic interventions should be directed at the entire family, not just at the identified adolescent. ${ }^{24}$

\section{Biological father's attitude toward the family conflicts}

Fathers did not have a prominent presence in most folktales. This may be because traditional male stereotypes show men as being primarily responsible for financial matters and less involved in household matters such as emotional conflicts between family members. ${ }^{25}$ One hypothesis is that, rather than introducing an undisclosed father role, a bad mother was substituted with an evil stepmother, with whom the child could become angry without feeling guilty or overwhelmed by unnatural feelings. ${ }^{26}$ In the case of stepmothers in Korean folktales, it is suggested that fathers were not highlighted because of the characteristics of matrilineal societies as the country transitioned from a matriarchal to a patriarchal society. ${ }^{27}$ Therefore, the conflict in the stepmothers' tales is not a trilateral problem based on the father, stepmother, and daughter, but a dual opposition between the stepmother and the daughter. While the phenomenon in stepmother fairy tales is a domestic problem, there are some scholars who interpret it as a problem in Korean society. ${ }^{27}$ In particular, the father who is indifferent to his child's suffering, the incompetent father who does not protect his own child from a stepmother's maltreatment, and the father who is influenced by the stepmother's schemes to hurt his child are compared to a king who is indifferent to his people's suffering. It was unimaginable to criticize the incompetence of or fault the king in the monarchy. In folktale tradition, the hope would be that these tales would twist the king's mistakes, and the king would come to his senses to correct politics and defeat the villainous powers.

\section{Time to shift from a wicked stepmother to a stepmother}

This study has several limitations. As the authors are clinicians rather than experts in culture, anthropology, or folktales, there are limits to interpreting the contribution of fairy tales to the society and culture. Also, authors may not read between the lines, and may understand the fiarytales ostensibly. The failure to provide social implications with the results of this study is due to the lack of capacity in the authors' subspecialty. Collaboration with related field experts is needed. There was also a language barrier. Unfortunately, it was difficult for the authors to properly introduce many of the great Korean papers about traditional folklores previously published. Despite these limitations, the findings from this study have noteworthy implications for mental health experts and developmental specialists working with families, especially children in stepfamilies.

In conclusion, the stepmothers found in Grimm brothers' folktales (representative of Western culture), and Korean folktales (representative of Eastern culture) were wicked ones who abused their stepchildren. In the West, jealousy was the primary reason for abuse, while greed was the predominant cause in the East. The stepmother's image was created as extremely bad. On the contrary, the biological mother had a relatively positive image. Folktales that emphasize the nega- 
tive aspects of stepmothers have a limited role in modern society, in which families with stepmothers have become more universal than in past centuries. The portrayals of stepmothers in European folktales, including Germany, and in traditional Korean folktales strongly suggest the need for a modern interpretation. The authors hope this study's findings will lead to cross-cultural research that can shift the image of a "wicked stepmother" to a "mother."

\section{Acknowledgments}

We thank Young Shin Lee to collect and classify the data, especially the huge amount of traditional Korean tales, Juhee Han to make the draft and Yejin Lee giving us beautiful imagination with the data. We also thank Yeon Jung Lee, Ram Hwangbo, and SungWoo Cho to make the draft.

This study was supported by the "Daegyun Bae's Ethnic Psychiatry Research Fund" (2016) from the Korean Foundation of Neuropsychiatric Research.

\section{Conflicts of Interest}

The authors have no potential conflicts of interest to disclose.

\section{Author Contributions}

Conceptualization: Geon Ho Bahn, Minha Hong. Data curation: Minha Hong. Formal analysis: Gen Ho Bahn, Minha Hong. Funding aquisition: Geon Ho Bahn. Investigation: Minha Hong. Methodology: Geon Ho Bahn. Project administration: Geon Ho Bahn. Writing_original draft: Minha Hong. Writing - review \& editing: Geon Ho Bahn. All authors read and approved the final version of the manuscript.

\section{ORCID iDs}

$\begin{array}{ll}\text { Geon Ho Bahn } & \text { https://orcid.org/0000-0002-3550-0422 } \\ \text { Minha Hong } & \text { https://orcid.org/0000-0003-4924-1107 }\end{array}$

\section{REFERENCES}

1. MacDonald WL, DeMaris A. Parenting stepchildren and biological children: the effects of stepparent's gender and new biological children. J Fam Issues 1996;17:5-25.

2. Ambert AM. Being a stepparent: live-in and visiting stepchildren. J Marriage Fam 1986;48:795-804.

3. Miller A, Cartwright C, Gibson K. Stepmothers' perceptions and experience of the wicked stepmother stereotype. J Fam Issues 2018;39:19842006.

4. Coleman M, Ganong LH. Remarriage and stepfamily research in the 1980s: increased interest in an old family form. J Marriage Fam 1990; 52:925-940.

5. Watson PA. Ancient Stepmothers: Myth, Misogyny and Reality. Leiden: EJ Brill; 1995.
6. Bahn GH, Lee S, Hong M, Lee YJ. Characteristics of caregivers in Disney animations. Psychoanalysis 2019;30:18-22.

7. Park YS. A Comparative Study on 'Kongjui Patjui' and 'Komehuku Awahuku'. Jpn Culture Stud 2007;23:209-249.

8. Reider NT. "Hanayo no hime: 'Blossom princess' a late medieval stepdaughter story and provincial customs." Asian Ethnol 2011;70:59-80.

9. Chung M. Encyclopedia of Korean Folk Literature. Seoul: National Folk Museum of Korea;2014. Available at http://folkency.nfm.go.kr/en/main.

10. Darnell R. American anthropology and the development of Folklore scholarship: 1890-1920. J Folklore Instit 1973;10:23-39.

11. Tatar M. The Hard Facts of the Grimm's Fairy Tales: Expanded Second Edition. Princeton, NJ: Princeton University Press; 2003.

12. Zipes J. The Complete Fairy Tales of the Brothers Grimm, All New 3rd Edition. New York: Bantam Books; 2003.

13. Han YJ. Aspects of conflict appearing in the folktales about stepmothers. J Ewha Korean Lang Lit 2012;30:107-149.

14. Cho JH. A study of Yangsojeojeon: concentrated on the connection aspect of a literary work and female heroic nature of the central character. Res Old Korean Novel 2010;30:345-374.

15. Chun J. Encyclopedia of Korean Folk Literature, Vol 1, 2. Seoul: National Folk Museum of Korea; 2012. Available at http://folkency.nfm. go.kr/kr/main.

16. Behrooz A. Wicked women: the stepmother as a figure of evil in the Grimms' fairy tales. Retrospect J [Internet] 2016:10. Available at: https:// retrospectjournal.com/.

17. Suh YS. Image and function of stepmother in "The Stepmother Song". Stud Pract Folklorist 2016;27:259-283.

18. Ben-Yehuda N. The European witch craze of the 14th to 17th centuries: a sociologist's perspective. Am J Sociol 1980;86:1-31.

19. Williams $C$. Who's wicked now? The stepmother as fairy-tale heroine. Marvels Tales 2010;24: 255-271.

20. Lee JS. Traditional image of stepmother: the establishment process and its meaning. Yoksa wa Hyonsil (Quarterly Rev Korean History) 2004; 51:135-163.

21. Noy D. Wicked stepmothers in Roman society and imagination. J Fam Hist 1991;16:345-361.

22. Anderson ER, Rice AM. Sibling relationships during remarriage. Monogr Soc Res Child Dev 1992;57:149-177.

23. Visher E, Visher JS. Therapy with Stepfamilies. Oxfordshire: Routledge; 1996.

24. Hetherington EM. Family functioning in nonstepfamilies and different kinds of stepfamilies: an integration. Monogr Soc Res Child Dev 1999;64:184-191.

25. Threfall JM, Kohl PL. Addressing child support in fatherhood programs: perspectives of fathers and service providers. Fam Relat 2015; 64:291-304

26. Bettelheim B. The Uses of Enchantment: The Meaning and Importance of Fairy Tales. New York: Random House LLC; 2010.

27. Choi W. A study on the type of the hermit folktale's tradition and Korean’s consciousness. Korean Folklore 2006;44:491-532. 